\title{
Effect of rumen-protected methionine supplementation to diets of Holstein dairy cows on their lactation performance
}

\author{
R. Salama ${ }^{1}$, M. A. El Sysy ${ }^{1,}$, , Sh. M. Fouda ${ }^{1}$ and A. A. Awad ${ }^{1}$ \\ 1 Animal Production Department, Faculty of Agriculture, Al-Azhar University, Nasr City, Cairo, Egypt \\ *Correspondence: elsysy@azhar.edu.eg (M. Elsysy)
}

\begin{abstract}
The objective of the present study was to evaluate the effect of rumen-protected methionine supplementation to diets of high producing Holstein dairy cows on milk yield and milk chemical composition. Ninety-nine pregnant Holstein dairy cows were randomly assigned to three nutritional groups to receive a total mixed ration and supplemented with rumen protected methionine (RPM) as; Smartamin ( $\left.\mathrm{T}_{1}\right)$ or Met55 ( $\left.\mathrm{T}_{2}\right)$ or non-supplemented (the control), at 260 days late gestation. Although, the two treated groups, ( $\mathrm{T}_{1}$ and $\mathrm{T}_{2}$ ) were daily supplemented with RPM for 30 days pre- and another 30 days post-partum; different experimental groups including the control one were daily provided with $60 \mathrm{~g} / \mathrm{h}$ choline chloride (Reashour) and $300 \mathrm{~cm}^{3}$ propylene glycol/ h, as an additional supply, during the same treating periods. Different experimental groups were fed a basal ration (16.2 CP \% and 70 TDN \%) during pregnancy and (16.4 CP \% and $74 \mathrm{TDN} \%$ ) during lactation. Results obtained showed that, supplementing different experimental groups with either Smartamin or Met55 did not improve $(p<0.05)$ cows actual milk yield, $3.5 \%$, fat corrected milk (FCM), energy corrected milk (ECM), milk fat yield nor protein yield kg.h.d ${ }^{-1}$. Supplementing Holstein dairy cows with (RPM) did not lead to any significant improvement $(p<0.05)$, neither in animals feed conversion ratio, nor milk chemical composition traits. Animals body condition score (BCS) differed $(p<0.05)$ among different experimental groups due to their yielding productivity in the former breeding season. However, lower milking group tended to have an improved BCS (3.79), but without significant difference with highly producing ones. In conclusion, Smartamin as (RPM) supplement was favored than that of Met55, if there were a necessity to be provided to lactating cows under the local environment.
\end{abstract}

Keywords: Body condition score; Lactation performance; Holstein dairy cows; Rumen-protected methionine (RPM).

\section{INTRODUCTION}

Protein is one of the major limiting nutrients in the diets of lactating dairy cows (Koenig and Rode, 2001). Ruminal microflora are capable of synthesizing all essential amino acids in required amounts. Protein available for absorption in the ruminant intestine is derived from ruminal microbes and dietary protein that escapes degradation during passage through the rumen (Dhiman and Satter, 1997). High producing dairy cows require greater amounts of dietary proteins. These proteins need to be of proper amino acid balance and in many times high producing dairy cows need additional amounts of certain amino acids that are deficient in the diet. This has stimulated increased interest in the area of amino acids nutrition in ruminant animals. Schwab et al. (1992), Rulquin et al. (1993), Armentano et al. (1997), Bequette et al. (1998), NRC (2001), Doepel et al. (2004), Lapierre et al. (2006), and Benefield et al. (2009) suggested that methionine might be one of the most limiting amino acids in dietary situation Methionine is an important amino acid diet of dairy cows, because it was required for milk protein synthesis (Leonardi et al., 2003). In addition, methionine is the source of the methyl donor S-adenosyl methionine, the metabolite that provides methyl groups in a variety of reactions including the de novo synthesis of choline from phosphatidyl-ethanolamine. Balancing rations with methionine supplementation to improve the profile of essential amino acids in metabolizable protein is fundamental to allowing the feeding of lower levels of dietary crude protein (CP) and rumen undegradable protein (RUP), maximizing lactation performance and minimizing $\mathrm{N}$ excretion. In several studies, postruminal infusion of methionine has been shown to improve milk yield and milk fat (Rulquin et al., 1993), or yield of milk protein, especially casein (Rulquin et al., 1993; Pisulewski et al., 1996). The most efficient approach to increase the supply of absorbable methionine to dairy cows is to include a rumen-protected methionine. Supplementing the diets of dairy cows with ruminally-protected methionine has been shown to increase milk yield (Robinson et al., 1995; Wu et al., 1997; Xu et al., 
1998), milk lactose (Robinson et al., 1995), and more frequently milk protein (Robinson et al., 1995, 1998, 1999; Wu et al., 1997; Xu et al., 1998). Therefore, the objective of the present study was to evaluate the effect of rumen-protected methionine supplementation to diets of high producing Holstein dairy cows on milk yield and milk chemical composition.

\section{MATERIALS AND METHODS}

\section{Animals feeding and management}

The present experiment was carried out in the Egyptian Company for Beef and Milk Production, belongs to Kassem Group, Al-Amal City, km 39, Cairo-Ismailia desert high way, Cairo Governorate during the period (2016). Ninetynine pregnant Holstein dairy cows mid to late lactation, with an average parity ranged between (3.39-3.59 seasons) were randomly assigned at 260 days late gestation to three nutritional groups (each of 33 cows / group) to investigate the effect of dietary supplement of (RPM) for 60 days i.e. 30 days prepartum and another 30 days postpartum on Holstein cows daily milk yield and milk chemical composition, besides its influences on cows reproductive performance, thereafter. Two types of (RPM) were used; Smartamine ${ }^{\mathrm{TM}}$ (protected methionine with Vinylpyridine / styrene copolymer $29 \%$, DL methionine $70 \%$ and moisture 1\%) in capsulated form (12 g.h.d $^{-1}$ Smartamine $\left.{ }^{\mathrm{TM}}\right), 90 \%$ ruminal. by-pass. The second type of (RPM) was DL-Met (55\% protected methionine) $25 \mathrm{~g} . \mathrm{h} . \mathrm{d}^{-1}, 55 \%$ ruminal bypass methionine. Different nutritional groups including the control one were routinely and daily supplemented with $60 \mathrm{~g}$ Reashour and 300 $\mathrm{cm}^{3}$ Propylene glycol .h. $\mathrm{d}^{-1}$ for 30 days during late pregnancy and another 30 days at early lactation, while pregnancy diagnosis was applied two months after the $1^{\text {st }}$ fertilization service, using rectal palpation method.

Pregnant Holstein cows (260 day on late gestation) were randomly assigned to one of the following nutritional groups; control was fed the basal ration without (RPM) supplement $(\mathrm{C}), \mathrm{T}_{1}$ were daily supplemented with $12 \mathrm{~g}$ Smartamin $^{\mathrm{TM}} . \mathrm{h}^{\mathrm{d}} \mathrm{d}^{-1}$, while $\mathrm{T}_{2}$ pregnant cows were daily supplemented with (Met 55) 25 g.h.d ${ }^{-1}$. Different nutritional groups were fed a standard diet formula during pregnancy and lactation (Tables 1, 2, 3 and 4) at 11-12 am.

Animals were daily offered $18 \mathrm{~kg}$ concentrate feed mixture $+16 \mathrm{~kg}$ corn silage $+8 \mathrm{~kg}$ green berseem $+2.5 \mathrm{~kg}$ ground rice straw $+600 \mathrm{~g}$ berseem hay at pregnancy, which provides 16.2 $\mathrm{CP} \%$ and $70 \%$ TDN, (Table 4).

During lactation, animals were raised on 14.0 $\mathrm{kg}$ concentrate feed mix. $+9 \mathrm{~kg}$ green berseem + $19.5 \mathrm{~kg}$ corn silage, which provides $16.4 \mathrm{CP} \%$ and $74 \%$ TDN (Table 4). Animals were raised under semi-opened sheds, while current fresh drinking water and veterinary care were available all the day time. Daily (RPM) supplements were routinely drugs for pregnant Holstein cows of both $T_{1}$ and $T_{2}$ groups for 30 days prepartum and another 30 days postpartum. Daily milk yield was automatically detected and recorded using (Afi Farm program system).

\section{Milk measurements}

Accurate daily milk yield (MY) /h /d, daily corrected milk to $3.5 \%$ fat, protein and fat yield in kg.h.d ${ }^{-1}$ were estimated according to NRC (2001), while energy corrected milk (ECM) according to the equation derived by Sjaunja et al. (1990).

\section{Milk determination and milk chemical analysis}

Representative milk samples were collected from different lactating nutritional groups at 5, 10, 15 and 45 days post-partum and early lactation, stored in standard plastic bottles and kept frozen until later chemical analysis. Different representative milk samples were subjected to chemical analysis for fat $(\mathrm{F})$, protein (P), lactose (L), total solids (TS), solids not fat (SNF) and somatic cell count (SCC), using milk scan apparatus (Model 133B; N. FOSS Electrictric, Denmark), belongs to the International Livestock Management Training Center Laboratories, Sakha, Kafr Elshaikh, Animal Production Institute, Ministry of Agriculture.

\section{Body condition score (BCS)}

Experimental animals were routinely subjected and justified to BCS before the initiation of the study, taking in consideration, cow's milk yield in the former previous season. Animals BSC were classified into three categories i.e. one month before calving (0), at calving (1) and at peak of lactation (2), and according to the milk yield productivity of the herd in the previous milking season to; lower producing ones (1); medium (2) and highly producing (3). The effect of feeding (RPM) supplement to lactating dairy cows on animals BCS was also estimated. 


\section{Statistical analysis}

Data were analyzed as a randomized complete block design with the General Linear Model, (SAS, 2002) for analysis of variance to determine difference between treatments and periods. Means and standard error of the means (SEM) were calculated. The significance of difference between means were tested for significances using the L.S.D test, according to Duncan (1955) at the pre-set level of $5 \%$. The statistical model for the trial was as follows:

$Y_{i j}=\mu+T_{i}+P_{j}+e_{i j}$

Where: $Y_{i j}=$ variable studied during the period, $\mu$ = overall mean of the population, $T_{i}=$ effect of treatment $(\mathrm{i}), P_{j}=$ effect of period $(\mathrm{j})$ and $e_{i j}=$ error associated with each $(\mathrm{Y})$.

\section{RESULTS AND DISCUSSION}

Effect of dietary rumen protected methionine supplement on Holstein cow's dairy milk yield

Data presented in Table (5) indicated significant differences among different experimental groups in different milk production traits. Results obtained showed higher $(p<0.05)$ daily milk yield $\mathrm{kg} / \mathrm{h}$ for the control group i.e. non protected methionine supplement, but without significant difference with Smartamin group $\left(\mathrm{T}_{1}\right)$. And both the two groups surpassed $(p<0.05)$ Met55 group $\left(\mathrm{T}_{2}\right)$.

Fat corrected milk (FCM) to $3.5 \%$ fat in different experimental cow groups led to the same trend, since the control group (deficient Met diet) recorded.

The higher $(p<0.05)$ daily $(\mathrm{FCM}) 37.96 \mathrm{~kg} \cdot \mathrm{h} . \mathrm{d}^{-1}$ in compare with both the two supplemented groups, i.e. $T_{1}$ and $T_{2}$, respectively.

Energy corrected milk showed the same trend, like that previously detected in Holstein cows actual and fat corrected milk. Energy corrected milk equation variables depended mainly on; $\mathrm{kg}$ milk yield .h.d $\mathrm{d}^{-1}$, fat, protein and lactose $(\mathrm{g} / \mathrm{kg}$ milk). And hence, the control group cows recorded higher $(p<0.05)$ values in such variables, it was a reliable prediction to exhibit higher $(p<0.05)$ fat and energy correct milk values. On the contrarily, both of $\mathrm{T}_{1}$ and $\mathrm{T}_{2}$ did not differ significantly from each other. However, Met55 $\left(\mathrm{T}_{2}\right)$ group, still indicated the lower $(p<0.05)$ milk yield estimates in different milk yield terminology in compare with both of the control group and the corresponding Smartamin one. Estimation of both of fat and protein yield in $\mathrm{kg}$ per head per day led to the same result, which was previously detected in the dairy productive traits. This matter might lead to decide that, supplementing Holstein dairy cows with both the two (RPM) forms did not lead to any positive influences on the productive performance of dairy cows in different yielding terms i.e. daily milk yield, FCM, ECM, nor fat and protein $(\mathrm{kg} / \mathrm{d})$. Inconsistent results were reported by earlier investigators, and while some pointed out to positive responses of dairy cows to (RPM) supplements, other studies did not show any response in milk percentage or yield with the addition of protected methionine (Socha et al., 2005; Ali et al., 2009; Giallongo et al., 2016; Pereira et al., 2017; Toledo et al., 2017 and Tamura et al., 2019).

Robinson et al. (1995) investigated the responses of cows to supplemental ruminally protected (RP) lysine and methionine in a diet designed to meet, but not exceed requirements for $\mathrm{CP}$ and ruminally degraded protein (RDP), and calculated to be deficient in delivery of intestinally lysine and methionine. That and other studies (Robinson, 1996) demonstrated that supplemental (RPLM) could increase milk production and milk fat, protein and lactose. However, results among experiments were not consistent, and production responses to supplemental RP methionine, RP lysine or RPLM have not been detected in several studies, he added. The author attributed such inconsistencies to more than one reason; that other AA's might be more deficient rather than lysine, methionine or to the competition between both the two AA's at the same intestinal absorptive site. It was of great interest to point out that the higher $(p<0.05)$ fat and protein yield $\mathrm{kg} / \mathrm{d}$ for the control Holstein cows group in the present study might be mainly referred to their higher $(p<0.05)$ milk yield production/.h.d-1 rather than any other factors. The scientific investigation of milk chemical composition in the same table pointed out to insignificant differences among different experimental groups in different traits of milk chemical composition.

On the light of the present results it could be concluded that supplementing different Holstein cows under the study with ruminal protected methionine in both the two (RPM) forms was of no necessity. The control Holstein cows group (Met-deficient diet) indicated higher $(p<0.05)$ 
productive yield performance in compare with both the two Met supplemented groups.

Data of somatic cell counts in the same table indicated higher $(p<0.05)$ values for both the control and Met 55 groups in compare with Smartamin one. Such result might be puzzling and out of explanation. And, although it was really accepted for cows of the control group due to their higher $(p<0.05)$ milk yield, which might have a negative stress on secreted cells of the udder tissue, but it was not true, nor accepted for Met 55 which indicated lower $(p<0.05)$ milk yield. Such later observation for Met 55, might be referred to clinical disorders, not more.

\section{Milk chemical composition:}

Date presented in Table (5) illustrated the effect of dietary ruminally protected methionine supplement to Holstein dairy cows on milk chemical composition. Results obtained pointed out to insignificant difference among different experimental cow groups in different milk chemical traits. Fat percentage ranged between $3.01 \%$ for Met 55 to $3.20 \%$ for the control, protein content ranged between $3.55 \%$ for the control to $3.61 \%$ for Met 55, lactose ranged between $4.73 \%$ for Smartamin to $4.76 \%$ for Met 55, TS ranged between $12.06 \%$ for Smart to $12.20 \%$ for the control, while SNF ranged between $9 \%$ for both the control and Smartamin to $9.05 \%$ for Met 55.Such results might lead to suggest that both the two supplemented (RPM) forms did not have any significant impact on milk chemical composition. Inconsistent results were reviewed by many different authors, and although most of them are pointing out to positive effects of (RPM) on milk chemical composition, particularly protein percentage, (Rulquin and Delaby, 1997; Wu et al., 1997; Armentano et al., 1993 and Berthiaume et al., 2006), others did not find any significant positive effects. Moreover, studies of NRC (2001), indicated that protein content of milk is more responsive than milk yield to supplemental methionine. It was also concluded that the increase in milk protein percentage are independent from that of milk yield. Similar results were shown by Polan et al. (1991), Ali et al. (2009), Lara et al. (2006) and Engel et al. (2006) and many others, who illustrated that addition of protected methionine to highly producing cows' diets did not show any response on milk protein percentage or yield, non-fat content.

On the light of the present results, it could be concluded that supplementing Holstein dairy cows herein the present study by ruminally protected methionine either in capsulated form as Smartamin or as Met 55 did not have any positive impact on cows daily milk yield or milk chemical composition. Such results might suggest also that experimental animals were maintained under better managerial and feeding conditions, hence there were no necessity to an additional amino acid supply, since it did not lead to any positive influences on daily milk yield or milk chemical composition.

Effect of supplemental ruminal protected methionine to Holstein cows on animals feed conversion ratio.

Data presented in Table (6) indicated significant differences among different experimental groups in feed conversion ratio (FCR). Results obtained favored the control cow groups as the most efficient one $0.58 \mathrm{~kg}$ DMI $/ \mathrm{kg}$ (FCM), but without significant difference with Smartamin group (0.64 kg DMI $/ \mathrm{kg}$ FCM). Cows supplemented with Met 55 indicated the lowest (FCR), $0.69 \mathrm{~kg}$ DMI $/ \mathrm{kg}$ FCM. The better feed conversion of the control group cows might be mainly referred to their higher $(p<0.05)$ milk production /h / day i.e. $37.96 \mathrm{~kg}$ FCM h/day in compare with both the two supplemented groups. It was of great interest to point out that dietary supplementation of (RPM) did not lead to improve cow's milk production. However, Smartamin was favored than that of Met55 as a (RPM) supplement.

Inconsistent results were reported in this concern, and while Wiese et al. (2003) with cattle and Obeidat et al. (2008) on Awassi ewes pointed out to insignificant effects of (RPM) on either animals ADG or (FCR); others indicated contrast results, (Oke et al., 1986; Wright and Loerch, 1988).

Effect of feeding ruminally protected methionine on body condition score (BCS) of dairy Holstein cows

\section{Cows BCS; one month before calving}

Date presented in Tables (7, 8 and 9) showed BCS of Holstein cows at different physiological and productive stages. Results in Table (7) concerning body condition score of experimental animals indicated insignificant effect to ruminally protected methionine supplement on animals (BCS), since animals were experienced 30 days before the expected calving time. 
However, figures obtained indicated nearly similar (BCS) ranged between 3.57 for cows of the control group to 3.59 for animals which supplemented with Met 55. Body condition score of different experimental groups indicated similar randomized groups. However, BCS of different experimental groups due to the previous lactating productivity in the former lactating season pointed out to significant difference among groups. Animals of lower productivity showed higher $(p<0.05)$ BCS, but without significant difference with higher producing ones. Such result seems to be accepted for the low producing group, but it might lead to real confusion for the higher producing one, unless the later group had have good nutritional and managerial care during the previous lactating season, hence they were maintained in good (BCS).

Animals with higher productivity in the former lactating season were really expected to lose more body weight due to the exhausting effect of milk secretion on animal body reserves. However, such result might lead to suggest that cows of highly producing group was provided with highly managerial and nutritional state, good and positive energy balance which in turn resulted in maintaining them in highly BCS. According to, Bewley et al. (2008); Bastin and Gengler (2013), BCS of an animal is one of the indicator traits for evaluating animal's nutritional state, which is closely connected with animal fertility, productivity and animal health. It was always used as the basic tool for the effective management of dairy cow breeding, being an accurate indicator to justify animal's body reserves and energetic state of the organism (Veerkamp et al., 2001).

Results presented in Table (7) indicated also that medium lactating cow group showed lower $(p<0.05)$ BCS, a result which was suggested to be referred to clinical health disorders. However, animals with different BCS showed in general good BCS, one month before calving, ranged between 3.38 for medium group to as high as 3.79 for low cow group. This result coincided with both of Bewley et al. (2008) and Salfer et al. (1995) who claimed that, cows should calve at 3.25 - 3.75 (BCS).

\section{Cows BCS at calving}

Data presented in Table (8) showed insignificant impact of different ruminally protected methionine supplement to pregnant
Holstein cows on cows BCS. Figures obtained were 3.44, 3.40 and 3.42 for the control pregnant cows and both of Smartamin and Met 55 groups, respectively. This result might be expected due to the shorter feeding treatment (four weeks prior to the expected calving date). On the other hand, different groups showed insignificant difference in BCS at calving, ranged between 3.36 for the medium lactating group to 3.52 for the low producing one. The matter which might lead to suggest that different experiment groups had have good BCS at calving and very good energy balance, since pregnant cows should calve at 3.25 - 3.75 BCS, (Bewley et al., 2008).

It was of great interest to point out that the statistical significance in cows BCS, one month before calving (Table 7), tended to be disappeared at calving. The matter which might point out to good feeding and managerial system of the herd which led in turn to good BCS of cows at parturition.

Effect of dietary supplementation of ruminally protected methionine on BCS of dairy Holstein cows at peak of lactation

Results obtained in Table (9) showed insignificant effect of (RPM) supplement to different experimental groups on cows BCS at peak of lactation. Figures obtained ranged between 2.71 for Smartamin group to 2.88 for the control lactating group. This matter might lead to suggest a positive energy balance and good managerial and feeding program provided for different experimental groups, which led in turn to maintain animals with good body reserves. However, it was of great interest to note, that different experimental groups tended to lose insignificant weight, 45 days after calving and early lactation as a natural physical state to milk secretion process.

Results reported by Vandehaar et al. (1999) and Pires et al. (2013) pointed out that cows lose significant amount of muscles during the first weeks of lactation; using amino acids in her muscles to produce glucose (gluconeogensis). Therefore, high protein ration was needed before calving to build up muscle reserves that can be drawn at early lactation for glucose production, hence rations dietary protein must be increased to 16 and $17 \% \mathrm{CP}$, during such critical period. However, some authors do not support increasing diet protein either as rumen by-pass protein or even when adding essential amino 
acids in rations as means of improving health or milk production.

On the light of the present results, animals were offered $16 \% \mathrm{CP}$ rations and supplemented with dietary fat would expected in turn to have good and positive energy balance. And, although experimental animals under investigation in the present study were supplemented with (RPM) either as Smartamin or Met 55, however such by pass methionine did not affect positively experimental animals live body weight, or animals BCS (Table 9).

\section{CONCLUSION}

As a final conclusion, supplementing experimental animals with ruminally protected methionine did not result in improving animals BCS at peak of lactation in compare with the control group one. Significant differences among different experimental groups $(p<0.05)$ due to amounts of milk secretion. It was shown that highly producing animals in the present season showed lower BCS (2.64) in compare with lower yielding ones (3.01), but insignificant BCS with medium yielding cows (2.76). Such observation substantiated our knowledge about the effect of milk yield on cows BCS. Higher producing cows tended to lose more weight and lower BCS and vice versa for lower producing ones. And as a general conclusion, supplementing lactating animals under the study with (RPM) during pregnancy and lactation did not have any significant impact on animals BCS. On the light of the present results, keeping pregnant Holstein cows under good feeding and managerial programs, might lead in turn to higher milk yield and good body condition score of cows without any necessities to an additional feed supplements. Smartamin as (RPM) supplement was favored than that of Met55, if there were a necessity to be provided to lactating cows under the local environment.

\section{REFERENCES}

Ali, C., Sharif, M., Nisa M., Javaid, A., Hashmi, N., Sarwar, M., 2009. Supplementation of ruminally protected proteins and amino acids: feed consumption, digestion and performance of cattle and sheep. Int. J. Agric. Biol. 11, 477-482.

Armentano, L.E., Bertics, S.J., Ducharme, G.A., 1997. Response of lactating cows to methionine or methionine plus lysine added to high protein diets based on alfalfa and heated soybeans. J. Dairy Sci. 80, 1194-1199.

Armentano, L.E., Swain, S.M., Ducharme, G.A., 1993. Lactation response to ruminally protected methionine and lysine at two amounts of ruminally available nitrogen. J. Dairy Sci. 76, 2963-2969.
Bastin, C., Gengler, N., 2013. Genetics of body condition score as an indicator of dairy cattle fertility. Biotechnol. Agron. Soc. Environ. 17 (1), 64-75.

Benefield, B.C., Patton, R.A., Stevenson, M.J., Overton, T.R., 2009. Evaluation of rumen-protected methionine sources and period length on performance of lactating dairy cows within Latin squares. J. Dairy Sci. 92, 44484455.

Bequette, B.J., Backwell, F.R.C., Crompton, L.A., 1998. Current concepts of amino acid and protein metabolism in the mammary gland of the lactating ruminant. J. Dairy Sci. 81, 2540-2559.

Berthiaume, R., Thivierge, M.C., Patton, R.A., Dubreuil, P., Steven-Son, M., McBride, B.W., Lapierre, H., 2006. Effect of ruminally protected methionine on splanchnic metabolism of amino acids in lactating dairy cows. J. Dairy Sci. 89, 1621-1634.

Bewley, J.M., Schutz, M.M., 2008. Review: an interdisciplinary review of body condition scoring for dairy cattle. Prof. Anim. Sci. 24, 507-529.

Dhiman, T.R., Satter, L.D., 1997. Yield response of dairy cows fed different proportions of alfalfa silage and corn silage. J. Dairy Sci. 80, 2069-2082.

Doepel, L., Pacheco, D., Kennelly, J.J., Hanigan, M.D., Lopez, I.F., Lapierre, H., 2004. Milk protein synthesis as a function of amino acid supply. J. Dairy Sci. 87, 12791297.

Duncan, D.B., 1955. Multiple range and multiple F-test. Biometrics. 11, 1.

Engel, J., 2006. Supplemental Rumen-protected Cholineand Methionine for Lactating Dairy Cows. Ph.D. Thesis, The Ohio State University, Columbus, $\mathrm{OH}$.

Giallongo, F., Harper, M.T., Oh, J., Lopes, J.C., Lapierre, H., Patton, R.A., Parys, C., Shinzato, I., Hristov, A.N., 2016. Effects of rumen-protected methionine, lysine, and histidine on lactation performance of dairy cows. J. Dairy Sci. 99, 4437-4452.

Koenig, K.M., Rode, L.M., 2001. Ruminal degradability, intestinal disappearance and plasma methionine response of rumen-protected methionine in dairy cows. J. Dairy Sci. 84, 1480-1487.

Lapierre, H., Pacheco, D., Berthiaume, R., Ouellet, D.R., Schwab, C.G., Dubreuil, P., Holtrop G., Lobley, G.E., 2006. What is the true supply of amino acids for a dairy cow? J. Dairy Sci. 89 (E Suppl.), E1-E14.

Lara, A., Mendoza, G. D., Landois, L., Barcena, R., Sanchez Torres, M.T., Rojo, R., Ayala, J., Vega, S., 2006. Milk production in Holstein cows supplemented with different levels of ruminally protected methionine. Livest. Sci. 105 (1-3), 105-108.

Leonardi, C., Stevenson, M., Armentano, L.E., 2003. Effect of two levels of crude protein and methionine supplementation on performance of dairy cows. J. Dairy Sci. 86, 4033-4042.

NRC, National Research Council. 2001. Nutrient Requirements of Dairy Cattle, 7th edition. National Academy Press, Washington DC.

Obeidat, B.S., Abdullah, A.Y., Awawdeh, M.S., Kridli, R.T., Titi, H.H., Qudsieh, R.I., 2008. Effect of methionine supplementation on performance and carcass characteristics of Awassi ram lambs fed finishing diets. Asian-Aust. J. Anim. Sci. 21, 831-837.

Oke, B.O., Loerch S.C., Deetz, L.E., 1986. Effects of rumen protected methionine and lysine on ruminant performance and nutrient metabolism. J. Anim. Sci. 62:1101-1112.

Pereira, A.B.D., Whitehouse, N.L., Aragona, K.M., Schwab, C.S., Reis, S.F., Brito, A.F., 2017. Production and nitrogen utilization in lactating dairy cows fed ground field peas with or without ruminally protected lysine and methionine. J. Dairy Sci. 100 (8), 6239-6255. 
Pires, J.A.A., Delavaud, C., Faulconnier, Y., Pomiès D., Chilliard, Y., 2013. Effects of body condition score at calving on indicators of fat and protein mobilization of periparturient Holstein-Friesian cows. J. Dairy Sci. 96 (10), 6423-6439.

Pisulewski, P.M., Rulquin, H., Peyraud, J.L., Verite, R., 1996. Lactational and systemic responses of dairy cows to postruminal infusions of increasing amounts of methionine. J. Dairy Sci. 79 (10), 1781-1791.

Polan, C.E., Cummins, K.A., Sniffen, C. J., Muscato, T.V., Vicini, J.L., Crooker, B.A., Clark, J.H., Johnson, D.G., Otterby, D.E., Guillaume, B., Muller, L.D., Varga, G.A. Murray, R.A., Peirce-Sandner, S.B., 1991. Responses of dairy cows to supplemental rumen-protected forms of methionine and lysine. J. Dairy Sci. 74, 2997-3013.

Robinson, P.H., 1996. Rumen protected amino acids for dairy cattle: What is the future? Anim. Feed Sci. Technol. 19, 81-86.

Robinson, P.H., Fredeen, A.H., Chalupa, W., Julien, W.E., Sato, H., Fujieda, T., Suzuki, H., 1995. Ruminally protected lysine and methionine for lactating dairy cows fed a diet designed to meet requirements for microbial and postruminal protein. J. Dairy Sci. 78, 582-594.

Robinson, P.H., Chalupa, W., Sniffen, C.J., Julien, W.E., Sato, H., Watanabe, K., Fujieda, T., Suzuki, H., 1998. Ruminally protected lysine or lysine and methionine for lactating dairy cows fed a ration designed to meet requirements for microbial and postruminal protein. J. Dairy Sci. 81, 1364-1373.

Robinson, P.H., Chalupa, W., Sniffen, C.J., Julien, W.E., Sato, H., Fujieda, T., Watanabe, K., Suzuki, H. 1999. Influence of postruminal supplementation of methionine and lysine, isoleucine, or all three amino acids on intake and chewing behavior, ruminal fermentation, and milk and milk component production. J. Anim. Sci. 77, 2781-2792.

Rulquin, H., Delaby, L., 1997. Effects of the energy balance of dairy cows on lactational responses to rumenprotected methionine. J. Dairy Sci. 80, 2513-2522.

Rulquin, H., Pisulewski, P.M., Verite, R., Guinard, J., 1993. Milk production and composition as function of postruminal lysine and methionine supply: A nutrient-response approach. Livest. Prod. Sci. 37, 6990.

Salfer, J.A., Linn, J.G., Otterby, D.E., Hansen, W.P., 1995. Early lactation responses of Holstein cows fed a rumeninert fat prepartum, postpartum, or both. J. Dairy Sci., $78,368-377$

SAS, 2002. Statistical Analysis System. Version 9.1.3. SAS Institute Inc. Cary, NC.

Schwab, C.G., Bozak, C.K., Whitehouse, N.L., Mesbah, M.M.A., 1992. Amino acid limitation and flow to duodenum at four stages of lactation. 1 . Sequence of lysine and methionine limitation. J. Dairy Sci. 75, 3486-3502.

Sjaunja L.O., Baevre, L., Junkkarinen, L., Pedersen, J., Setälä, J., 1990. A Nordic proposal for an energy corrected milk formula. Proc. 2nd Session of Committee for Recording and Productivity of Milk Animal Paris, p156.

Socha, M.T., Putnam, D.E., Garthwaite, B.D., Whitehouse, N.L., Kierstead, N.A., Schwab, C.G., Ducharme, G.A., Robert, J.C., 2005. Improving intestinal amino acid supply of pre- and postpartum dairy cows with rumen protected methionine and lysine. J. Dairy Sci., $88,1113-1126$.

Tamura, T., Inoue, K., Nishiki, H., Sakata, M., Seki, M., Koga, T., Ookubo, Y., Akutsu, K., Sato, S., Saitou, K., Shinohara, H., Kuraisi, T., Kajikawa, H., Kurihara, M., 2019. Effects of rumen-protected methionine on milk production in early lactation dairy cattle fed with a diet containing $14.5 \%$ crude protein. Anim. Sci. J. 90 (1), 62-70.

Toledo, M.Z., Baez, G.M., Garcia-Guerra, A., Lobos, N.E., Guenther, J.N., Treviso, E., Luchini, D., Shaver R.D., Wiltbank, M.C., 2017. Effect of feeding rumenprotected methionine on productive and reproductive performance of dairy cows. PLoS One. 12 (12), e0189117.

Vandehaar, M. J., Yousif, G., Sharma, B.K., Herdt, T.H., Emery, R.S., Allen M.S., Liesman, J.S., 1999. Effect of energy and protein density of prepartum diets on fat and protein metabolism of dairy cattle in the periparturient period. J. Dairy Sci. 82, 1282-1295.

Veerkamp R.F., Koenen, E.P.C., DeJong, G., 2001. Genetic correlations among body condition score, yield, and fertility in first-parity cows estimated by random regression models. J. Dairy Sci., 84, 2327-2335.

Wiese, S.C., White, C.L., Masters, D.G., Milton, J.T.B., Davidson, R.H., 2003. The growth performance and carcass attributes of Merino and Poll Dorset $\times$ Merino lambs fed rumen protected methionine (SmartamineTM-M). Aust. J. Agric. Res. 54, 507-513.

Wright, M.D., Loerch, S.C., 1988. Effects of rumen-protected amino acids on ruminant nitrogen balance, plasma amino acid concentrations and performance. J. Anim. Sci. 66, 2014-2027.

Wu, Z., Fisher, R.J., Polan, C.E., Schwab, C.G., 1997. Lactational performance of cows fed low or high ruminally undegradable protein prepartum and supplemental methionine and lysine postpartum. J. Dairy Sci. 80, 722-729.

$\mathrm{Xu}$, S., Harrison, J.H., Chalupa, W., Sniffen, C.J., Julien, W., Sato, H., Fuijeda, T., Watanabe, H., Ueda, T., Suzuki, H., 1998. The effect of ruminal bypass lysine and methionine on milk yield and composition of lactating cows. J. Dairy Sci. 81, 1062-1077. 
Table1. Concentrate mixed ration composition for Holstein cows during pregnancy and lactation.

\begin{tabular}{lll}
\hline \multirow{2}{*}{ Ingredients } & \multicolumn{2}{l}{ Ration composition $\%$} \\
& Pregnancy & Lactation \\
\hline Dried pelleted beet pulp & 19.86 & - \\
Corn gluten meal (66 CP \%) & 1.56 & - \\
Soybean meal, solv.(44 \% CP) & 21.94 & 13.72 \\
Linseed meal & 7.26 & 18.16 \\
Cracked rice grains & 20.53 & 35.40 \\
Ground yellow corn grains & 20.75 & 20.88 \\
Calcium soaps of fatty acids & 0.72 & 3.68 \\
Urea & - & 0.65 \\
Feed additives \% & & \\
Ca chloride & 1.34 & - \\
Mg Sulfate & 0.12 & - \\
Mg Oxide & 0.20 & 0.34 \\
Potassium carbonate & - & 0.49 \\
Sodium bicarbonate & - & 1.85 \\
Sodium chloride (Salt) & - & 0.74 \\
Multivita Vitamins & 1.39 & 0.15 \\
Multivita Minerals & 0.12 & 0.15 \\
Bone meal & 3.0 & 1.54 \\
Bentonite & 1.21 & 0.74 \\
Limestone & - & 100 \\
Total & & \\
\hline & & \\
\hline
\end{tabular}

Table 2. Feed intake of pregnant Holstein cows (kg.h.d-1).

\begin{tabular}{lll}
\hline Ingredients & Intake $\left(\mathrm{kg} . \mathrm{h} \cdot \mathrm{d}^{-1}\right)$ & \\
& As Fed & $\mathrm{DM}$ \\
\hline Corn Silage & 15.94 & 4.78 \\
Alfalfa Meal, $(17 \% \mathrm{CP})$ & 0.64 & 0.57 \\
Ground Wheat Straw & 2.32 & 2.15 \\
Green Berseem & 8.153 & 0.82 \\
Dried Beet Sugar Pulp & 3.639 & 3.21 \\
Corn Gluten meal & 0.29 & 0.25 \\
Soybean Meal $(44 \% \mathrm{CP})$ & 4.02 & 3.58 \\
Linseed Meal & 1.33 & 1.2 \\
Cracked rice grain & 3.76 & 3.35 \\
Ground Corn Grain & 3.8 & 3.35 \\
Calcium soaps of fatty acids & 0.13 & 0.13 \\
Total intake & $\mathbf{4 4 . 0 2 2}$ & $\mathbf{2 3 . 3 9}$ \\
Feed additives \% & & \\
Ca Chloride & 0.25 & 0.25 \\
Multivita Vitamins & 0.02 & 0.02 \\
Multivita Minerals & 0.02 & 0.02 \\
Mg Sulfate & 0.25 & 0.25 \\
Mg Oxide & 0.04 & 0.04 \\
Bone meal & 0.55 & 0.53 \\
Bentonite & 0.22 & 0.22 \\
Total & $\mathbf{1 . 3 5}$ & $\mathbf{1 . 3 3}$ \\
Total Intake & $\mathbf{4 5 . 3 7 2}$ & $\mathbf{2 4 . 7 2}$ \\
\hline
\end{tabular}


Table 3. Feed intake of lactating Holstein dairy Cows (kg.h.d-1).

\begin{tabular}{lll}
\hline Ingredients & As Fed & DM \\
\hline Corn Silage & 19.48 & 5.84 \\
Green Berseem & 8.93 & 0.89 \\
Soybean Meal $(44 \% \mathrm{CP})$ & 1.86 & 1.66 \\
Linseed Meal & 2.47 & 2.23 \\
Cracked Rice grain & 4.81 & 4.28 \\
Ground Corn Grain & 2.84 & 2.50 \\
Calcium soaps of fatty acids & 0.5 & 0.48 \\
Urea & 0.09 & 0.09 \\
Total & $\mathbf{4 0 . 9 8}$ & $\mathbf{1 7 . 9 7}$ \\
Feed additives \% & & \\
Multivita Vitamins & & 0.02 \\
Multivita Minerals & 0.02 & 0.02 \\
Mg Oxide & 0.02 & 0.05 \\
Bone meal & 0.05 & 0.21 \\
Bentonite & 0.2 & 0.1 \\
potassium Carbonate & 0.1 & 0.07 \\
Sodium Bicarbonate & 0.07 & 0.25 \\
Limestone & 0.25 & 0.2 \\
sodium chloride & 0.2 & 0.1 \\
Total & 0.1 & $\mathbf{1 . 0 2}$ \\
Total intake & $\mathbf{1 . 0 1}$ & $\mathbf{1 8 . 9 9}$ \\
\hline
\end{tabular}

Table 4. Nutritive values of Holstein cows' rations during pregnancy and lactation (on DM basis\%).

\begin{tabular}{lll}
\hline Item & Pregnancy ration \% & Lactation ration \% \\
\hline $\mathrm{CP}$ & 16.2 & 16.4 \\
$\mathrm{CP}^{-R D P}{ }^{1}$ & 7.5 & 9.1 \\
$\mathrm{CP}^{2} \mathrm{RUP}^{2}$ & 8.7 & 7.3 \\
$\mathrm{NFC}^{3}$ & 44.9 & 49.3 \\
$\mathrm{ADF}$ & 17.5 & 13.9 \\
$\mathrm{NDF}$ & 28.6 & 22.6 \\
Forage NDF & 17.1 & 15.4 \\
$\mathrm{EE}$ & 2.6 & 4.4 \\
$\mathrm{TDN}$ & 70.0 & 74.0 \\
$\mathrm{ME}(\mathrm{Mcal} / \mathrm{kg} \mathrm{DM})$ & 2.31 & 2.34 \\
$\mathrm{NEl}(\mathrm{Mcal} / \mathrm{kg}$ DM) & 1.45 & 1.49 \\
$\mathrm{DCAD}$ (mEQ/ kg) & -0.62 & 331 \\
\hline \multicolumn{2}{r}{ 1-CP-RDP; rumen degradable protein } & 2-CP-RUP; rumen undegradable protein \\
\multicolumn{2}{r}{ 3- Non fiber carbohydrates } & 4- DCAD; dietary cation-anion difference
\end{tabular}


Table 5. Productive performance of Holstein dairy cows as affected by dietary protected methionine supplementation.

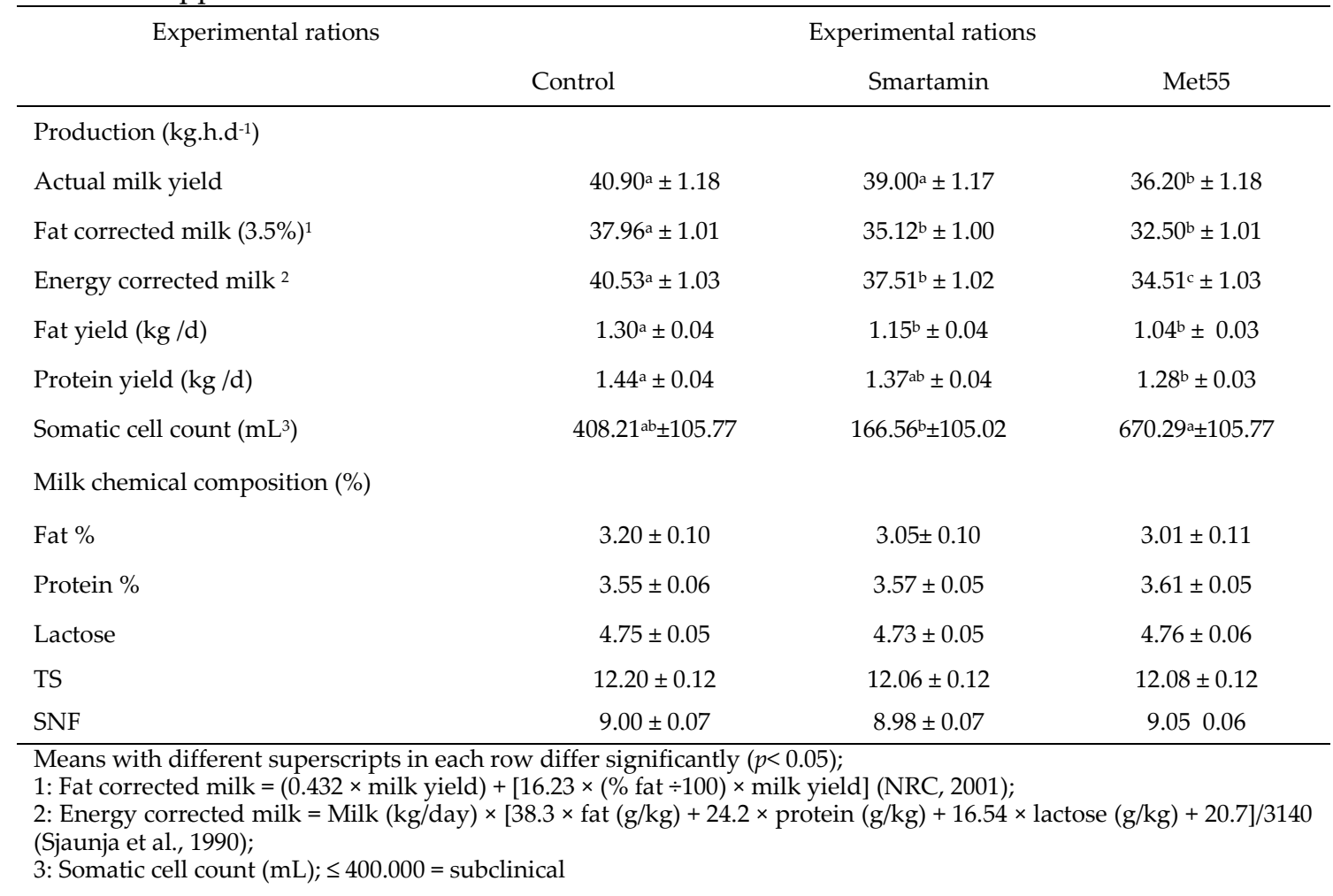

Table 6. Effect of supplemental ruminal protected methionine to Holstein dairy cows on animals feed

\begin{tabular}{|c|c|c|c|}
\hline \multirow[t]{2}{*}{ Item } & \multicolumn{3}{|c|}{ Intake $/ \mathrm{h} / \mathrm{d}(\mathrm{kg})$ on DM basis } \\
\hline & Control & Smartamin & Met55 \\
\hline Concentrate (TMR $\left.{ }^{1}\right)$ & 14.0 & 14.0 & 14.0 \\
\hline \multicolumn{4}{|l|}{ Roughage: } \\
\hline Corn silage & 6.00 & 6.00 & 6.00 \\
\hline Green berseem & 0.90 & 0.90 & 0.90 \\
\hline Total intake $/ \mathrm{h} / \mathrm{d}$ & 20.90 & 20.90 & 20.90 \\
\hline Avg. FCM ${ }^{2} / \mathrm{h} / \mathrm{d}$ & $37.96^{\mathrm{a}}$ & $35.12^{\mathrm{b}}$ & $32.50^{\mathrm{b}}$ \\
\hline $\begin{array}{l}\text { Feed Conversion } \\
(\mathrm{kg} \text { intake /kg FCM) }\end{array}$ & $0.58^{\mathrm{b}} \pm 0.02$ & $0.64^{\mathrm{ab} \pm 0.02}$ & $0.69 \mathrm{a} \pm 0.03$ \\
\hline
\end{tabular}

TMR; total mixed ration 2- FCM; $3.5 \%$ fat corrected milk

Table 7. Body condition score (BCS) of lactating dairy cows, one month before the expected calving date.

\begin{tabular}{|c|c|c|c|c|c|}
\hline \multirow{2}{*}{ Item } & \multirow{2}{*}{ Milk yield classes } & \multicolumn{3}{|c|}{ Experimental rations } & \multirow{2}{*}{$\begin{array}{c}\text { Overall } \\
\text { mean }\end{array}$} \\
\hline & & Control & Smartamin & Met55 & \\
\hline \multirow{4}{*}{ BCS } & 1(low) & $3.65 \pm 0.26$ & $4.19 \pm 0.29$ & $3.53 \pm 0.22$ & $3.79^{\mathrm{a}} \pm 0.15$ \\
\hline & 2 (Mid) & $3.57 \pm 0.14$ & $3.13 \pm 0.15$ & $3.43 \pm 0.14$ & $3.38^{\mathrm{b}} \pm 0.09$ \\
\hline & 3 (High) & $3.50 \pm 0.29$ & $3.43 \pm 0.18$ & $3.81 \pm 0.29$ & $3.58^{\mathrm{ab}} \pm 0.15$ \\
\hline & Overall mean & $3.57 \pm 0.13$ & $3.58 \pm 0.12$ & $3.59 \pm 0.13$ & \\
\hline
\end{tabular}


Table 8. Effect of ruminal protected methionine supplement on body condition score of cows at calving.

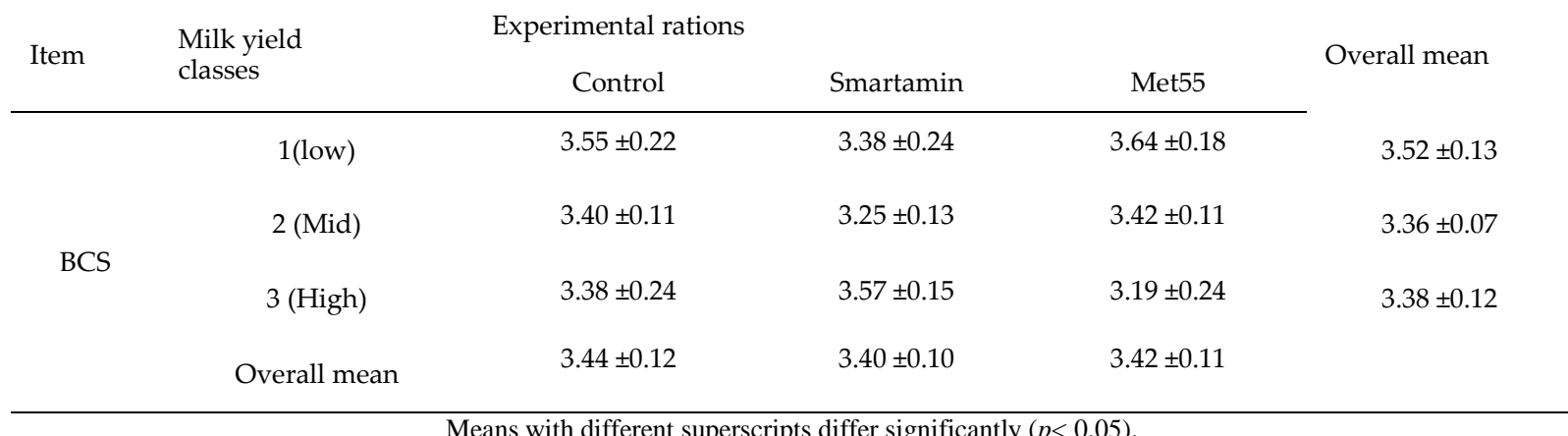

Means with different superscripts differ significantly $(p<0.05)$

Table 9. Body condition score of the cows at peak of lactation.

\begin{tabular}{llllll}
\hline \multirow{2}{*}{ Item } & Milk yield classes $^{*}$ & \multicolumn{3}{c}{ Experimental rations } & Overall mean \\
\cline { 3 - 5 } & & Control & Smartamin & Met55 & \\
\hline & 1 (low) & $2.9 \pm 0.21$ & $2.81 \pm 0.24$ & $3.32 \pm 0.18$ & $3.01^{\mathrm{a}} \pm 0.12$ \\
BCS & 2 (Mid) & $2.81 \pm 0.11$ & $2.68 \pm 0.12$ & $2.79 \pm 0.11$ & $2.76^{\mathrm{ab}} \pm 0.07$ \\
& 3 (High) & $2.94 \pm 0.24$ & $2.64 \pm 0.14$ & $2.38 \pm 0.24$ & $2.64^{\mathrm{b}} \pm 0.12$ \\
& Overall mean & $2.88 \pm 0.11$ & $2.71 \pm 0.10$ & $2.83 \pm 0.11$ & \\
\hline
\end{tabular}

Means with different superscripts differ significantly $(p<0.05) ;{ }^{*}$ BCS of the lactating cows under the study (2016) 


\title{
تاثير تدعيم علاثق ابقار الهولشتاين الحلابة بالميثيوين المحي على كفاءة انتاجيتها من اللبن
}

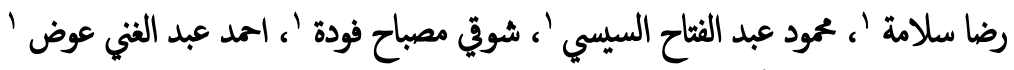

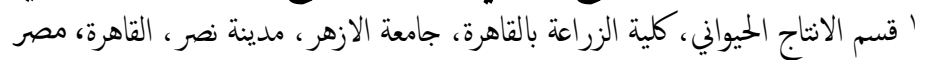

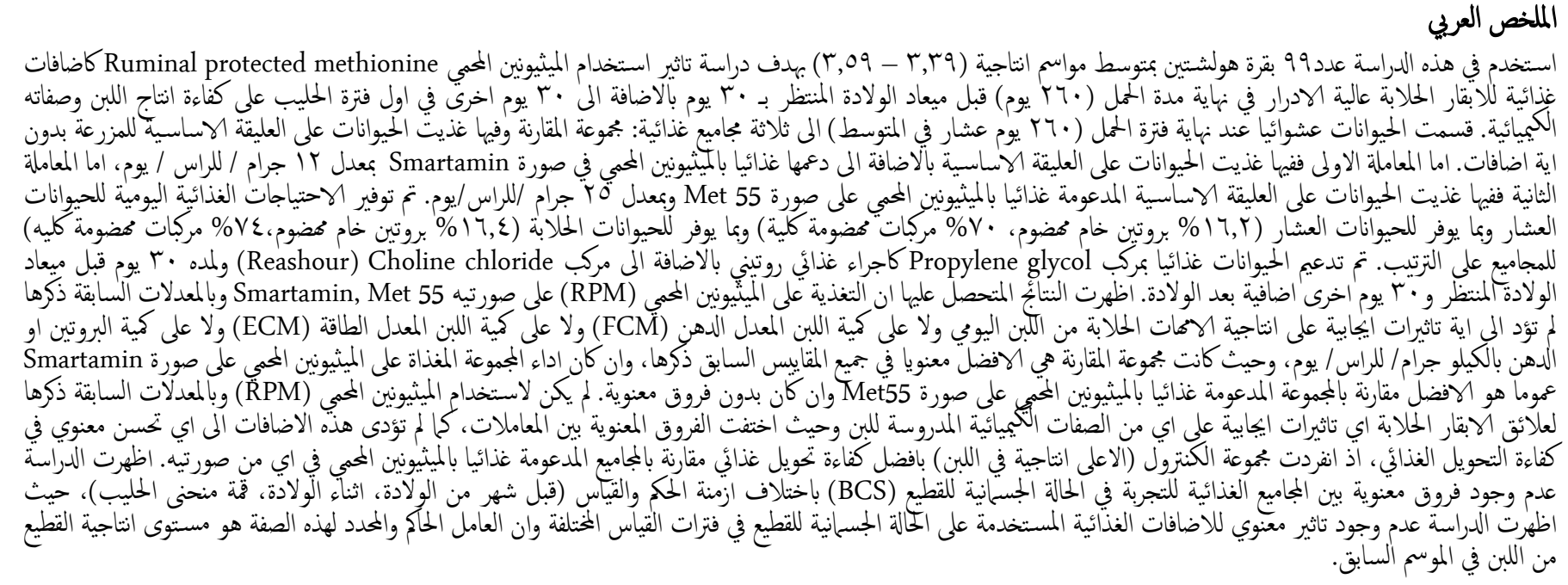

